\title{
The Complexity of Theories on Rural Development in Europe: An Analysis of the Paradigmatic Case of Almería (South-east Spain)
}

\author{
Emilio Galdeano-Gómez,* José A. Aznar-Sánchez and \\ Juan C. Pérez-Mesa
}

\begin{abstract}
In recent decades several theories on rural development have been expounded in an attempt to explain some experiences of regional economic growth or to provide recommendations on rural development policies. The objective of this article is to revise this open debate and attempt to introduce more concerns about the delimitation of theories and the mosaic of rural areas in Europe. In this context the present article analyses the paradigmatic development of Almería (south-east Spain) based primarily on agriculture in a process categorised as an economic miracle. Some authors have attempted to explain this success by mechanisms associated with the endogenous development approach. Nevertheless, this study reveals that Almería's development experience can be categorised as a miscellaneous one, and a mixture of development approaches should therefore be considered as opposed to unidirectional models. This also shows the importance of keeping open the debate on the impact of agrarian activity on rural development.
\end{abstract}

\section{Introduction}

The number of theories on regional development is constantly increasing. Indi1 vidual theories differ in terms of the characterisation of the principal actors and the mechanisms of regional development. In most cases, nothing like a commonly accepted paradigm on regional development exists (Ward and Hite I998; Suchacek and Malinovsky 2007).

In the course of the last two decades the field of regional development has witnessed a distinct move from exogenous approaches (driven from outside) to endogenous ones (driven from within). Most recently, however, rather than reverting to the old endogenous doctrine, the exogenous Keynesian paradigm was replaced by a neo-endogenous doctrine, which accentuates the creation of general conditions for 
simulating inner endogenous developmental possibilities in individual regions (for example, Ray 200I). In most cases this differentiation is accentuated in the context of recommendations for the formation of regional policies, as is the case of rural development policy in Europe. Nevertheless, the nature of rural areas and the challenges they face vary considerably across Europe, and as a result what is understood to constitute rural development policy also varies (Baldock et al. 200I). These facts also lead us to consider that certain eclectic stages of regional development are path-dependent upon the history of regional development paradigms (Hassapoyannes et al. 1998; Suchacek and Malinovsky 2007).

However, there is general consensus that regional development can scarcely be achieved without regional economic growth. The question is whether case-specific regional economic development can be explained by different development approaches or whether a given developmental approach can be conceptualised by certain regional paradigms. An additional question focuses on the role of rural development policies in specific cases. This study takes as a reference the paradigmatic economic growth of Almería province in Spain, whose agricultural and economic development lacks a regional policy to a great extent. ${ }^{\mathrm{I}}$

The development of Almería's economy is described by Mota et al. (I996) as the Almería economic miracle. This province ranked $50^{\text {th }}$ of a total of 5 I Spanish provinces as regards per capita gross domestic product (GDP) in I969 but its position had improved to $24^{\text {th }}$ by 2002 and between 1994 and 2005 the growth in GDP in Almería nearly quadrupled relative to the regional and national averages (Instituto Nacional de Estadística 2008). This growth has been driven by intensive horticultural and the marketing services and related auxiliary industry, which have all benefited growers of all sizes and all sectors of the economy. Recently Downward and Taylor (2007, p. 28I) have cited the following description by Almería's Director of Agriculture:

This is the most social [equitable] level of agriculture in the world, not even the best communist system would have achieved what has been achieved in Almería ... and for people who maybe 50 years ago would have only had a herd of goats.

This phenomenon (which is most likely unprecedented in other Spanish provinces) may constitute an example of endogenous development (Vázquez-Barquero 2002) based on the effective use of natural resources, considerable business initiative and local productive organisation, and on the creation and diffusion of innovative productive systems (such as social capital and networking). All of these have led to the accumulation of capital and know-how, together with a high degree of competitiveness in the national and international agrifood context. This process, however, has not been exempt from relevant exogenous components. For example, apart from its connection from the outset with agents and circuits of the European and international agrifood system, the productive development began by being based on several governmental policies and programmes for the development of irrigation infrastructure in the I950s and ig6os. In the framework of the so-called colonisation policy, these programmes had the basic aim of improving the productivity of areas of scant production (usually due to unfavourable natural conditions) and via small family-owned farms. However, without a doubt, the subsequent development of an intensive, competitive export-oriented agriculture is a far cry from the intentions or 
achievements of the above-mentioned rural policy, as can be seen from the overall result this policy achieved in different Spanish regions (García-Latorre et al. 200I). We should also bear in mind that from the I970s onwards this area's development had no government planning or support whatsoever; not even the different European Union (EU) programmes for rural development (PRODER, LEADER and so on).

On the other hand, although local institutional development has not followed a parallel process, over the last few years there have been certain signs which could be considered to belong to the perspective of neo-endogenous development. These include in particular the increasing participation of several public organisations (such as the university) and concerns about regional differentiation in institutional policies.

The objective of this article is to show how this case-specific economic development can be explained by the elements of different individual theories on regional development. Therefore, the study also attempts to provide considerations of complementarity among development theories that can be explained by this specific regional development.

\section{Agricultural development versus rural development in Europe}

Although agriculture remains the predominant land use in rural Europe, it no longer dominates socially or economically. In the EU the sector accounts for only 6 per cent of employment and even plays a minor role in rural employment and the GDP of rural regions, despite the slight increase due to the recent extension of the Union to include 27 member countries, for example, $4.9 \%$ of employment in the EU-25, as compared to $3.7 \%$ in EU-I5 (European Commission 2007).

Whereas agriculture remains a strategically significant policy sector and is the major force determining the rural environment, most rural areas rely to a diminishing extent on farming. As rural areas have come to fulfil other functions, so other public policies (apart from agriculture) have impinged on rural areas and governments have been drawn in to resolve issues concerning social and economic development in rural areas through rural development policy. However, the nature of rural areas and the challenges they face vary considerably across Europe with the consequence that what is understood to constitute rural development policy also varies (see, for example, Baldock et al. 200I). Table 1 shows the two main perceptions. The common feature is a perspective that cuts across sectoral concerns and has a territorial orientation. As a deliberate focus of activity, rural development policy has emerged as a counterpoint to, and in the intersection between, two other established fields: agricultural policy and spatial policy (Ward et al. 2005).

Despite the existing heterogeneity, the most accepted trend over the last two or three decades in European rural development policy, under the predominant conception of a model of endogenous development (for example, the LEADER programme), has been to promote increasing diversification in order to accommodate various economic activities and new lifestyles. This is based on the argument that every region or locality should develop by taking advantage of whatever existing or potential local comparative advantage may lie within the spectrum of economic activities, noting that activities such as organic farming, maintenance of landscape, tourism, energy harvesting and employment creation through labour-intensive services should be 
Table 1: Agrarian versus rural development perceptions

\begin{tabular}{|c|c|}
\hline Agrarian & Rural development \\
\hline $\begin{array}{l}\text { Farmer's interests are the same as the rural } \\
\text { interest }\end{array}$ & $\begin{array}{l}\text { Local actors represent a broad range of } \\
\text { interests according to their social } \\
\text { affiliation and economic status }\end{array}$ \\
\hline $\begin{array}{l}\text { Multifunctionality of rural areas is a } \\
\text { historical outcome of traditional farming }\end{array}$ & $\begin{array}{l}\text { Rural areas' multifunctionality is due to } \\
\text { internal diversity and external } \\
\text { expectations or pressures }\end{array}$ \\
\hline $\begin{array}{l}\text { Viable rural areas depend upon farming } \\
\text { activity, both economically and culturally }\end{array}$ & $\begin{array}{l}\text { A competitive farming sector is not always } \\
\text { a prerequisite for viable rural areas }\end{array}$ \\
\hline
\end{tabular}

Source: Baldock et al. (2001).

promoted (Pausewang I995). In many cases the focus on agriculture as the main activity has been considered misleading (for example, Terluin 2003). The inexorable decline in primary sector employment and the depopulation of rural areas, particularly in many parts of southern Europe and the more remote mountainous regions of central and northern Europe, probably constitute the main reason for the political orientation described (Ward et al. 2005).

Flynn and Lowe (I994) emphasise that the decline in importance of agriculture as a sector in rural areas alongside the restructuring process (in advanced countries) has triggered, in various combinations, a complex new set of economic, social, political and cultural relationships. In the authors' view, these relationships are not necessarily dominated by economic parameters (for example, the structure of local economy and employment) but are also influenced by political and social factors. In contrast, Cuddy (2005) notes that the creation of value added in a sustainable and competitive market framework is the foundation of (economic) wellbeing in rural areas. From this point of view the problem faced by agricultural-based regions resides in the thinness or non-existence of markets and the imperfect performance of markets and information flows.

Nevertheless, some agricultural-based regions continue to show a self-sustained process of growth. For example, authors such as Hassapoyannes et al. (I998) state that this is the case of agricultural development models in regions of Greece, Italy, Holland and Spain, which are based on a series of comparative advantages that sustain endogenous development. Among these elements are the following advantages:

- production of high-quality products (high value added per unit of end product)

- low use of external inputs in agriculture

- specific production patterns allowing for alternatives to modernisation schemes

- combination of non-agricultural activities

- recognition of the contribution of local factors and knowledge of local styles of farming.

Together with these common elements, in each region certain specific factors have allowed the comparative advantages to be utilised (Hassapoyannes et al. 1998). In 
Italy, food chains have been the point of departure in examining meat, wine and tobacco production. In the case of Spain it has been the co-operative basis (small farmers) and marketing strategies. In Greece, the agricultural sector is characterised by the persistence of traditional relations in production, such as family farming and diversification. In Holland, the focus was on the social organisation of the production process and marketing strategies. However, these authors describe these examples of competitive agriculture as a component to bear in mind rather than the basis on which rural development can be generalised.

Additionally, in recent decades, European rural policy has played a positive role (to varying degrees) in securing these competitive advantages. For example, Tarditi (2000) stresses that after joining the European Community, Italy implemented probably the worst structural policy in Europe, with inadequate results for agricultural restructuring and rural development. He attributes this poor performance to both the agricultural policy measures implemented by the regional and national authorities and the local implementation of structural policy and rural development.

Nonetheless, there is much debate amongst academic researchers in rural studies regarding the theories or models of economic development in rural regions, and the role of the agricultural sector and rural development policy in stimulating economic growth in rural regions (Lowe et al. I993; Cloke I997; Ray 200I; Terluin 2003). The literature suggests three major approaches to rural development: an exogenous, an endogenous and a neo-endogenous development approach.

\section{Trends in regional development theories}

\section{From exogenous to endogenous perspectives}

In recent decades, there has been a shift in rural development policy from an exogenous model to approaches informed by an endogenous model. The shift (depicted in Table 2) has been far from complete. The classic formulation of rural development dominant in post-war Europe, was a model that put industrialisation at the centre of development. The key principles of this model centred on economies of scale and concentration, considering that the function of rural areas was primarily to provide food for the expanding cities.

By the late I970 this model was falling into disrepute. It was criticised as dependent development, reliant on continued subsidies and the policy decisions of distant agencies or boardrooms. It was seen as distorted development, which boosted single sectors, and selected settlements and certain types of business (for example, progressive farmers) but left others behind and neglected the non-economic aspects of rural life. It was cast as a destructive form of development that erased the cultural and environmental differences of rural areas and was considered to be dictated development devised by external experts and planners outside the local rural areas (Ward 2002; Ward et al. 2005).

Endogenous approaches are based on the assumption that the specific resources of an area (natural, human and cultural) hold the key to its sustainable development. Whereas exogenous rural development saw its key challenge as overcoming rural 
Table 2: Exogenous and endogenous rural development models

\begin{tabular}{|c|c|c|}
\hline & Exogenous development & Endogenous development \\
\hline Key principle & $\begin{array}{l}\text { Economies of scale and } \\
\text { concentration }\end{array}$ & $\begin{array}{l}\text { Harnessing local (natural, human } \\
\text { and cultural) resources for } \\
\text { sustainable development }\end{array}$ \\
\hline Dynamic force & $\begin{array}{c}\text { Urban growth poles (drivers } \\
\text { exogenous to rural areas) }\end{array}$ & Local initiative and enterprise \\
\hline $\begin{array}{l}\text { Functions of } \\
\text { rural areas }\end{array}$ & $\begin{array}{l}\text { Food and primary products for } \\
\text { expanding urban economies }\end{array}$ & Diverse service economies \\
\hline $\begin{array}{l}\text { Major rural } \\
\text { development } \\
\text { problems }\end{array}$ & $\begin{array}{l}\text { Low productivity and } \\
\text { peripherality }\end{array}$ & $\begin{array}{l}\text { Limited capacity of areas and } \\
\text { groups to participate in } \\
\text { economic activity }\end{array}$ \\
\hline $\begin{array}{l}\text { Focus of rural } \\
\text { development }\end{array}$ & $\begin{array}{l}\text { Agricultural modernisation: } \\
\text { encourage labour and capital } \\
\text { mobility }\end{array}$ & $\begin{array}{l}\text { Capacity-building (skills, } \\
\text { institutions, infrastructure): } \\
\text { overcoming exclusion }\end{array}$ \\
\hline Criticism & $\begin{array}{l}\text { Dependent, distorted, destructive } \\
\text { and dictated development }\end{array}$ & $\begin{array}{l}\text { Not practical in contemporary } \\
\text { Europe }\end{array}$ \\
\hline
\end{tabular}

Source: Ward et al. (2005); Buchenrieder et al. (2007).

differences and distinctiveness through the promotion of universal technical skills and the modernisation of physical infrastructure, endogenous development sees the key challenge as valorising difference through the nurturing of locally distinctive human and environmental capacities (van der Ploeg and Long I994; van der Ploeg and van Dijk I995; Shucksmith 2000). In this model local resource endowments (climate, land fertility and environmental quality) and the specific characteristics of human and cultural capital provide the fundamental conditions for long-term rural development. The main purpose of this perspective is to improve local economic and social circumstances through mobilising internal resources.

Towards a broad vision of endogenous development and the new concepts of neo-endogenous development and the knowledge economy

Given the great diversity of cases, and particularly in Europe, the recent literature on development has broadened the concept of endogenous development. Authors such as Vázquez-Barquero (2002) identify four roots of European endogenous development theories (Table 3). The first is the high theory of development, which looks at externalities in local economies that bring increasing returns to scale. The second is a dualistic growth theory, which involves capital accumulation during the growth process. The third theoretical root is dependency theory, which explains the domination of peripheral economies. Endogenous development theory and dependence theory share the view that technological dependence restricts growth and that a connection with the centre would promote growth in the peripheral economies. The fourth root is a territorial development theory that focuses on local initiatives and local development processes. 
Table 3: Theoretical roots of endogenous development

\begin{tabular}{|c|c|c|c|c|}
\hline $\begin{array}{l}\text { Endogenous development } \\
\text { characteristics }\end{array}$ & $\begin{array}{c}\text { High } \\
\text { development } \\
\text { theory }\end{array}$ & $\begin{array}{l}\text { Dualistic } \\
\text { growth theory }\end{array}$ & $\begin{array}{l}\text { Dependence } \\
\text { theory }\end{array}$ & $\begin{array}{c}\text { Territorial } \\
\text { development } \\
\text { theory }\end{array}$ \\
\hline \multicolumn{5}{|l|}{ Development potential } \\
\hline Resources & $\mathrm{X}$ & $\mathrm{X}$ & $\mathrm{X}$ & $\mathrm{X}$ \\
\hline Indivisibilities & $x$ & - & - & - \\
\hline \multicolumn{5}{|l|}{ Capital accumulation } \\
\hline Application of surplus & $x$ & $x$ & $x$ & - \\
\hline Innovation & $x$ & $x$ & $x$ & - \\
\hline Flexible labour market & - & $x$ & $x$ & $x$ \\
\hline \multicolumn{5}{|l|}{ External economies of scale } \\
\hline Organisation of production & $x$ & - & - & - \\
\hline Networking & - & - & - & - \\
\hline Urban relations & - & - & $x$ & - \\
\hline \multicolumn{5}{|l|}{ Institutional context } \\
\hline Institutional flexibility & - & $x$ & $x$ & - \\
\hline Organisation of society & - & $x$ & $x$ & - \\
\hline \multicolumn{5}{|l|}{ Local action } \\
\hline Local initiatives & - & - & - & $x$ \\
\hline Local control of development & - & - & - & $x$ \\
\hline
\end{tabular}

Source: Vázquez-Barquero (2002), Yamamoto (2007).

However, despite the broad nature of these conceptions, they do not suffice to explain the diversity and the different mechanisms in economic development across regions in Europe. For instance, the Agricultural and Employment in the Rural Regions project (Terluin and Post 2000) focused on employment performance and sought to identify the major factors that influenced job creation in leading and lagging EU rural areas (I8 case studies between I980 and I990). The distinction between the leading and lagging rural regions was established by the number of non-agricultural jobs created in these regions. The study was based on the interaction between local and external forces (between endogenous and exogenous development theories). The findings show that there is no unique development pattern towards the creation of jobs, but rather multiple development trajectories.

Another project, Dynamics of Rural Areas, investigated the factors of differential economic performance between rural areas which apparently possess similar economic, social and political conditions (I6 areas from Scotland, Germany, Greece and Sweden). The research was based on the hypothesis that the differential development of rural areas might be explained by the interaction of a combination of tangible and intangible factors and variables in specific local, regional and national contexts (Bryden and Hart 2004). The findings show that the importance of different tangible and intangible factors varied between successful and less successful regions. Intangible factors, such as community and culture, networks, institutions and governance, linked to human resources (for example, entrepreneurial qualities) and the ease of adaptation to the new political emphasis on market economy and devolved 
government were crucial for the differential economic performance (Bryden and Hart 2004). Although there is no unique development pattern for successful rural areas, some potential lessons and interrelated factors that explain the differential economic performance were outlined (Buchenrieder et al. 2007).

In addition, Dwyer et al. (2007) provide a study of the implementation of rural development policy instruments to achieve different objectives in different parts of Europe (across I3 EU countries, including three candidate countries). The findings stressed the considerable potential of rural development regulation in the evolution of EU rural development. However, the focus remained on agriculture and the resources fell far short of needs, particularly with regard to rural environment and the sustainable development of marginal areas. Authors such as Suchacek and Malinovsky (2007) and Buchenrieder et al. (2007) state certain concerns about the application of rural development policy in recently incorporated countries to the EU. There are differences between countries that see the rural development regulation as a tool to promote environmental land management and those who focus on agriculture modernisation (Buchenrieder et al. 2007). Terluin (2003) provides a critical analysis of some of the relevant theories that conceptualise the triggers behind economic development in rural regions in the EU. She shows that the mixed exogenous and endogenous development approach, the community-led development theory and the first hypothesis of Bryden's (2003) theory on the use of social and cultural capital are widely supported by empirical evidence.

To a great extent, these analyses and findings tend to show components of the recent theories on neo-endogenous development approach. The process of regional development was formed to be an intersection of new concepts, such as learning regions, flexible specialisation or industrial districts that underline the importance of profound spatial differentiation in institutional characteristics. ${ }^{2}$

Some authors (Lowe et al. I993; Ray 200I) have criticised endogenous development ideas. They argue that the notion of local rural areas pursuing socioeconomic development autonomous of outside influences (they are whether globalisation, external trade or governmental or EU action) may be an ideal but is not a practical proposition in contemporary Europe. Any locality will include a mix of exogenous and endogenous forces, and the local level must interact with the extra-local (High and Nemes 2007). The critical point is how to enhance the capacity of local areas to steer these wider processes, resources and actions to their benefit. This is the notion of neo-endogenous development. The focus then is on the dynamic interactions between local areas and their wider political, institutional, trading and natural environments, and how these interactions are mediated.

Taking as reference the EU's LEADER programme experiences, Ray (2003) argues that the key to conceptualising actions within neo-endogenous local initiatives is the role of human capital and the dynamics by which it accumulates in individuals, businesses and organisations. A knowledge economy approach to neo-endogenous rural development seeks to develop the human and social capital in networks of businesses, practitioners and agencies working in rural areas (Ward et al. 2005).

It is along these lines that the New Rural Economy project has been carried out, focusing on the role of institutions such as universities in this knowledge economy. Based on the experience of North-East England, this shows how capturing the 
Table 4: Neo-endogenous rural development model

(Following the structure of Table 2)

Key principle

Dynamic force

Functions of rural areas

Major rural development problems

Focus on rural development

Criticism
The interaction between local and global forces

Globalisation, rapid technological change in communications and information

Knowledge economy, dynamic participation of local actors in local and external networks and development processes

Resources allocation and competitiveness in a global environment

Enhancing local capacity and actors participation to direct local and external forces to their benefit

Operates at a level of insufficient empirical evidence

Source: Buchenrieder et al. (2007); authors.

knowledge of practitioners and researchers from both inside and outside the region, the project activities have sought to help unlock the potential and build the capacity of endogenous and neo-endogenous actors to plan and deliver rural development in that region (Ward et al. 2005).

Despite this experience and the consistency of this development approach, Buchenrieder et al. (2007) consider that more empirical evidence is required before it can be accepted. In particular the implications of engaging several institutions in a common development strategy may make the practical application of this approach difficult (Table 4).

\section{The case study: Almería's development}

\section{Methodology of analysis}

The case study method was selected (Yin I989). This allows an understanding of the evolution of this regional development at more than a superficial level. We used a retrospective analysis based on studies that focused on some components of the economic development and secondary statistical data. In the following subsection, a general retrospective is provided, outlining the main features of Almería's economic development. In the final subsection, the main factors of its success and their connection with the different development models are analysed. For these descriptions we have taken into account additional methodological aspects and considerations.

More specifically, this study bears in mind that when considering the success of a development model competitiveness is a common key factor (Terluin 2003). Competitiveness is the ability of each region to produce with a comparative advantage the goods and services that are demanded by the national and international system of which they form a part (Camagni I995; Esposti and Sotte 2002). Thus, in each stage of the development under analysis, it is not difficult to explain the causes and determining factors in transforming comparative advantages into competitive 
variables (for example, Galdeano and De Pablo I999). The difficulty in this case study resides in identifying the development models that accommodate this process. An additional issue is that this case study has not been analysed in the literature outlined in the previous section, possibly due the difficulty of defining a single model or because this development has been based on agriculture, rather than on recommendations from rural development policy, as indicated above.

Due to these issues, the approach followed consists of outlining the factors of competitiveness and identifying them as components of different development perspectives (Terluin and Post I999). Three stages of the historical process in this development are considered (for example, Martínez-Paz et al. 200I; Ferraro and Aznar 2008): (I) a mixed exogenous/endogenous development model in the beginning (I960s and I970s); (2) a reinforcement of the endogenous development model during the following decades (I980s and I990s); (3) economies of scale and concentration from the I990s and the consideration of neo-endogenous components.

\section{Data and features related to agriculture-based development}

The province of Almería has experienced an unprecedented transformation in terms of Spain's recent economic history. Until the end of the Ig6os all the social and economic indicators characterised Almería as a province that was underdeveloped and in a stage of decline. However, from that point on Almería's economy began a period of growth that produced development indicators higher than the regional and national average. This strong growth rate has made the province one of the most outstanding examples of convergence in the second half of the twentieth century. Almería passed from being one of the worst ranked provinces in Spain in terms of GDP to becoming the first province in Andalusia (southern Spain) and obtaining an intermediate position nationally, after gaining thirty percentage points (Figure 1).

The production sector structure in this province possesses unique traits with respect to those of Andalusia and Spain, namely, the importance of the primary sector and lack of industry. In 2006 the agrarian sector in Almería contributed $23.5 \%$ of the total gross value added, while in Andalusia it represented $7.8 \%$ and in Spain 4\% (Table 5). Therefore, in terms of production the sector is triple that of the regional average in the province and is nearly six times greater than the national average. Moreover, the substantial importance of agriculture in the province has been maintained over the last three decades, while in the contexts of Andalusia and Spain it has progressively lost its strength against the rest of the production sectors. As a result this trend has allowed the provincial agrarian sector to grow continuously both regionally (increasing from I7.I\% in 1995 to $28.2 \%$ in 2006 ) and nationally (from $4.3 \%$ to $7.5 \%$, respectively). From the point of view of employment, the importance of the sector in terms of production is highlighted even more considering that it accounts for $27.1 \%$ of provincial employment, as compared to I $2.2 \%$ at regional level (Andalusia) and only $7.4 \%$ at national level.

The credentials of intensive farming in Almería are outstanding. The land area dedicated to horticultural farming in greenhouses $(26,750$ ha) represents over half of the national total. More than $70 \%$ of this area is concentrated in the zone known as El Poniente, the most important centre of intensive farming in the world (United 


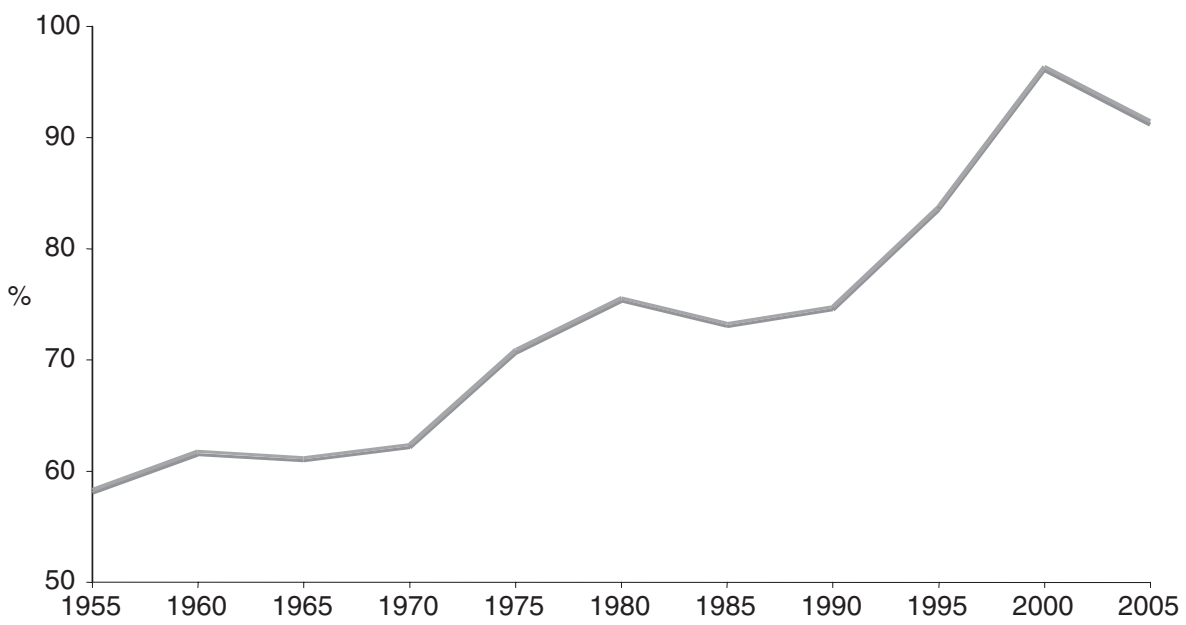

Figure 1: GDP per capita in Almería in relation to the GDP in Spain from 1955 to 2005 (\%)

Source: Instituto Nacional de Estadística.

Table 5: Production structure for Almería, Andalusia and Spain in 2007 (\%)

\begin{tabular}{|c|c|c|c|c|c|c|}
\hline & \multicolumn{2}{|c|}{ Almería } & \multicolumn{2}{|c|}{ Andalusia } & \multicolumn{2}{|c|}{ Spain } \\
\hline & GVA & Employment & GVA & Employment & GVA & Employment \\
\hline Agriculture & 23.5 & 27.1 & 7.8 & 12.2 & 4.0 & 7.4 \\
\hline Industry & 8.0 & 5.6 & 13.7 & 9.7 & 20.2 & 17.5 \\
\hline Construction & 10.4 & 10.5 & 12.2 & 11.5 & 10.0 & 11.3 \\
\hline Services & 58.1 & 56.8 & 66.2 & 66.6 & 65.7 & 63.9 \\
\hline Total & 100.0 & 100.0 & 100.0 & 100.0 & 100.0 & 100.0 \\
\hline
\end{tabular}

GVA, gross value added.

Source: Instituto Nacional de Estadística.

Nations Environment Programme [UNEP] 2005). In 2008 agricultural production increased to 2.95 million tons and turnover reached $€_{I, 4} 6_{3}$ million, making Almería the top vegetable growing province in Spain. Over half the produce is destined for foreign markets and the corresponding I.66 million tonnes that are exported make this province the largest Spanish exporter of fresh vegetable produce and create its trade surplus every year.

Its social importance is also relevant, as the sector was founded on a system of small-scale family farms and has been a key source of employment. The farmland is divided among 13,500 small-scale farmers and the sector provides direct employment to more than 40,000 workers annually. The family nature of the farms and their reduced size were characteristics that appeared at the beginning of the sector's development but have endured until the present day, making them their most 
characteristic and unique traits (García-Latorre et al. 200I; Downward and Taylor 2007). This further examined in the following section.

\section{Identification of components of development theories}

By means of this identification exercise, the study of this exceptional case allows us to show certain limitations of the development models over different periods of time, while assuming that this process is not totally linear. As Shucksmith (2010, p. 6) points out, development is non-linear, complex and continually emergent, popping up in unexpected ways from a variety of actors. In the history of this development we should therefore consider the simultaneous existence of components that can be ascribed to the three models described. However, considering the proposed stages, which cover a lengthy period of time, we see that in the case of Almería certain components stand out as main development drivers, and these may be linked more closely to one of the development theories, making it appear more important than the others.

A mixed exogenous and endogenous development model at the beginning. In Almería intensive farming represents the largest agrarian transformation that Spain has experienced in recent decades. When trying to explain the process that led to the emergence of this sector it is difficult to find similarities with the development of other farming regions (Mota et al. I996). Consequently, this phenomenon has been dubbed the Almería miracle. Nevertheless, beyond resorting to the notion of miracles to explain past events a collection of social, institutional, economic and technological factors exists which have combined to give rise to this process.

The natural conditions of this province were ideal for the growing of extra-early horticultural crops under plastic, since the benign climatic conditions and the elevated number of hours of sunlight permitted farming during times of the year when it was not possible in other European farming areas. In addition, the low and erratic rainfall was compensated by the abundance of subterranean water resources. However, in order to take advantage of these natural assets the contribution of an exogenous and institutional component was necessary. This came in the form of federal intervention via the National Colonisation Institute (the INC, in Spanish). In this way, access to underground aquifers was made possible thanks largely to institutional actions in the I950s, which promoted the use of the technology necessary for extracting this resource. This also contributed to breaking the technology blockade that would have impeded the development of other future technological innovations. Moreover, the intervention of the INC was not limited to providing water and electrical infrastructures; it also encouraged new people to settle in the area and offered them technical and financial advice. Its actions proved to be decisive as regards the social composition of the new sector as the allocation of small-scale parcels of land (3.5 ha) among settlers set the foundations for a family-farm model that has lasted until today (García-Latorre et al. 200I).

In addition to this institutional component, the human factor played a fundamental role in the sector's initial phase. The INC's work to settle the area was accompanied by a widespread response from families from nearby rural areas who were attracted in 
times of crisis by the proposition of easy access to land and the possibility of obtaining their own property, not to mention the high profitability these farms offered in comparison with traditional agriculture. With their strong work ethic and high levels of initiative these families took on the risk of farming on completely unirrigated terrain by means of a new growing technique that they put into practice and perfected with great ease, allowing them to increase output and obtain significant profits.

The technological component also made a fundamental contribution during the sector's first phase. At that time local innovations were developed and subsequently incorporated very rapidly by most of the farmers. The first step forward took place with the introduction of a farming technique called enarenado (the creation of an artificial soil), which completely transformed unproductive land into prosperous farms with higher and earlier yields (Tout I990). Later, people began to construct the first plastic greenhouses intended to provide effective protection against winds and low winter temperatures. This further contributed to increased yields, early harvests, quality produce and water conservation (Galdeano and De Pablo I999).

Finally, an exogenous component that helped to fuel the sector was the favourable conditions of international markets. During a time of growing open trade in the European market, the development of Almería's agriculture benefited from an expanding market for horticultural produce in general and, in particular, for out-ofseason produce (Pérez-Mesa 2007). This growing demand led to progressively larger yields and was the main reason for continued investment and development.

Reinforcement of the endogenous development model in the following decades. It was upon the above-mentioned foundations that Almería's intensive farming model developed over the course of the I96os and I970s. However, its consolidation took place in the Ig8os and I990s, fundamentally based on endogenous components with constant improvement in the fields of production and marketing.

In the field of production there has been a gradual substitution of employment for capital while at the same time maintaining the basic farm structure. The average farm size has also grown as a result of the accumulation of capital and technological improvements to greenhouses that permit the management of even larger areas. Despite this trend, the small dimensions which still characterise most farms allow them to be predominantly family-run firms, although there has been a growing movement towards contract labour. The need for labour from outside the family unit has grown progressively basically due to two new factors. On the one hand, this is because of economic reasons, as many of the agricultural workers, particularly women and young adults, have moved into the auxiliary and service sectors that have arisen around the agricultural sector. Secondly, since the mid-I980s farmers have tended to increase production by extending the surface area of crops in order to maintain their levels of profit; and they have also diversified the risk of fluctuations in prices on the international markets by broadening the range of produce supplied (Aznar and Sánchez 2000). As in other agricultural areas in Spain, the lack of labour, especially for occasional work, has been solved since the mid-I990s by employing foreign workers. Initially, the step from farming mainly with family workers to using a high level of employees, many of whom are immigrants, has not been well managed and the incorporation of this new workforce has given rise to difficulties that have 
become one of the main challenges facing this sector. This challenge is being met by introducing stricter regulation and contracting foreign workers in their country of origin. Nevertheless, the contribution of the immigrant workforce to Almería's intensive horticulture has become a relevant element. This workforce suits the particular characteristics of the local work market perfectly, as they are a very adaptable workers, and by occupying the lowest posts in the labour market they have permitted the professional and economic mobility of Spanish workers in a clear hierarchy of the labour market.

In this phase the technological component has maintained its contribution to development, allowing farming techniques to continue evolving thanks to the constant introduction of innovations geared towards growth that respond to the needs and peculiarities of the local area. The incorporation of new technology into farms during this period has been massive, substantially improving yields and allowing the average production per hectare to more than double, increasing from a little over 30 tons per ha in 1990 to more than 64 in 2008. Furthermore, this increased yield has produced an improvement in quality, an extension of the growing seasons and the harvesting of two and up to three crops a year, which is known as crop forcing (Tout I990; Ferraro and Aznar 2008).

The structure of local financing has constituted another of the factors that has allowed the production structure based on family firms to be maintained. Its growth was accompanied by the endogenous development of private financing structures and mechanisms for family firms. The private credit facilities offered by marketing firms, and particularly the rising importance of local credit entities, mainly the Caja Rural de Almería (now Caja Rural Intermediterránea, Cajamar) in the I960s as an agricultural credit co-operative (with a high degree of participation in capital from local farmers), were fundamental for continued investment, given the lack of foreign investment and particularly the lack of CAP Common Agricultural Policy or Spanish government support. ${ }^{3}$

The endogenous component of human capital has played a fundamental role in the technological field. On the one hand, it is important to note that most of the first settlers had prior experience in agricultural labour, particularly with horticultural or vine crops. Together with the fact that they were young and energetic, this made them more receptive to the incorporation of new farming techniques, which, in turn, drove them to participate in the constant development of improvements and create a favourable environment for technological innovation and its rapid and widespread implementation (García-Latorre et al. 200I). In addition, the generational renewal that is currently taking place with the incorporation of young farmers is helping to intensify this rejuvenation process by means of technological innovations. On the other hand, the constant incorporation of innovations, both in production processes and inputs, cannot be understood without considering the role played by agricultural engineers and technicians. Almería is an area in Spain which has the highest density of workers dedicated to technical agronomic consulting. In most cases they are not self-employed but rather belong to a business or institutional organisations carrying out a fundamental role in the release and dissemination of information through a series of channels designed around a network of both formal and informal contacts (Ferraro and Aznar 2008). 


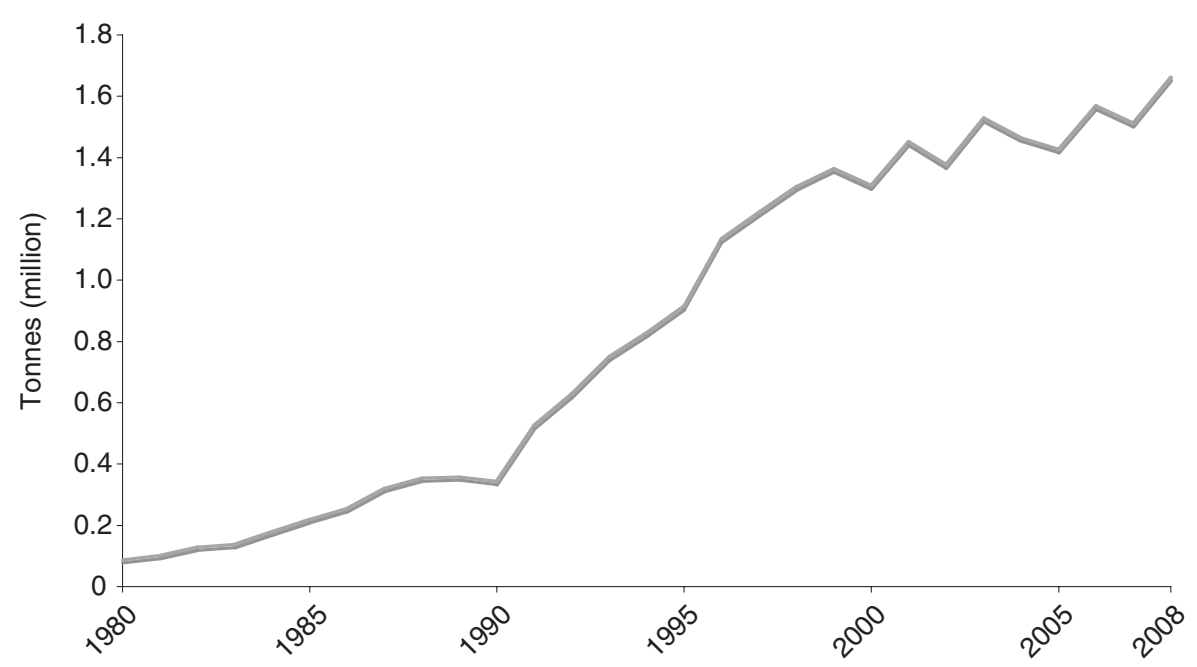

Figure 2: Evolution of horticulture exports from Almería Source: Instituto Nacional de Estadística.

The endogenous component of development is also absolutely dominant in the field of marketing. Over the years the structuring of distribution channels has been achieved following a local marketing model comprised of two methods, which both complement and compete against each other. Firstly, there were local sales by means of an auction system (exchanges), then subsequently direct sales to consumer markets developed through distribution companies organised by the growers themselves. Thanks to this model, practically all produce is currently marketed directly from Almería for both national and international markets. Apart from retaining more value added for the area and achieving better prices, the action of involving farmers in direct distribution has also allowed them to maintain direct contact with the markets, making them more inclined to favour innovation and adapt to the changing demand (Galdeano and De Pablo i999).

Finally, during this stage the sector underwent a significant reorientation towards international markets. The continued improvement of local distribution channels has permitted the rapid and constant incorporation of horticultural produce to the export market (Martínez-Paz et al. 200I; Pérez-Mesa 2007). From the second half of the I990s, sales in foreign markets continued to rise to the point where they had absorbed more than half of Almería's horticultural production (Figure 2). During this time this province became the largest exporter of fresh vegetables in Spain, representing about $30 \%$ of the national total in recent years. Furthermore, exports of horticultural produce have become the nucleus of Almería's exports, representing over $80 \%$ of provincial sales to foreign markets. This enormous exporting power exceeds provincial limits and reaches significant relevance on a regional scale as it represents almost Io\% of all Andalusian exports. 
From economies of scale and concentration to a consideration of neo-endogenous components. Economies of scale and concentration began to rise during this period as a result of a structure founded on the highest concentration of plastic greenhouses in the world. The provincial land area dedicated to horticultural greenhouse farming is currently situated at around 27,000 ha. Almería has the largest area of greenhouse crops of all Spanish provinces, representing more than half of the total area of greenhouses in Spain. This is even more significant considering Spain itself is a country with the most hectares dedicated to greenhouses in the whole Mediterranean basin, surpassing Italy, Turkey and Morocco. Furthermore, most of the greenhouse area in this province is concentrated in the El Poniente zone. In this area, of about 27,000 ha, there is a concentration of over $\mathrm{I} 6,000$ ha of greenhouses. The result is the emergence of a veritable sea of plastic visible from kilometres away that has taken on outstanding worldwide significance as one of the greatest territorial transformations to have taken place in the last third of the twentieth century. In fact, the concentration of greenhouses in El Poniente is one of the few man-made structures visible from space along with the Great Wall of China (UNEP 2005).

Nevertheless, derived from this concentration, the sector has to overcome some environmental issues. Until the I990s intensive horticulture was developed without any type of territorial planning and organisation, which produced negative environmental externalities: the extraction of sand from the costal area for agricultural use, the uncontrolled dumping of waste (both organic, plastic and packaging), the occupation of areas of environmental interest and landscape degradation, deficiencies in the road network, the invasion of the public hydraulic domain and the poor structure and functioning of territorial planning (Gómez 2003). The lack of planning at the start of the boom period, along with the continuous increase in the number of hectares under greenhouses, also led to the over-exploitation of some of the aquifers in the area. This pressure became manifest as unmistakable symptoms of degradation appeared in the aquifers, such as the progressive salinisation in the areas closest to the shore (Tout I990; Consejería de Agricultura y Medio Ambiente I99I). The solution to this problem began to be introduced at the end of the I980s in the form of generalised systems of water saving (such as drip irrigation and hydroponics) and the progress achieved in productivity per cubic metre (Colino and Martínez 2002; Galdeano-Gómez et al. 2008). The advent of the Plan Hidrológico de la Cuenca del Sur (Hydrological Plan for the Southern Basin) in the late I990s allowed an increase in the water supply (via desalinisation plants, reservoirs, reusage, and so on) and the study of the capacity and evolution of the aquifers with the aim of establishing a suitable framework to regulate demand (Ferraro 2000; Downward and Taylor 2007).

However, apart from the benefits derived simply from the enormous magnitude achieved by the sector, the formation of an agro-industrial cluster has acquired increasing relevance and can be considered an outstanding exponent of the endogenous development perspective (Ferraro and Aznar 2008). Since the beginning of the I990s a complex system of industrial activities and services has been growing, all revolving around the greenhouse farming that is the base of the current agroindustrial cluster (Figure 3). This system is experiencing constant dynamism, as is demonstrated by its evolution, performance, the number of companies in this area, job creation and sales in international markets. All this has led the sector to achieve 


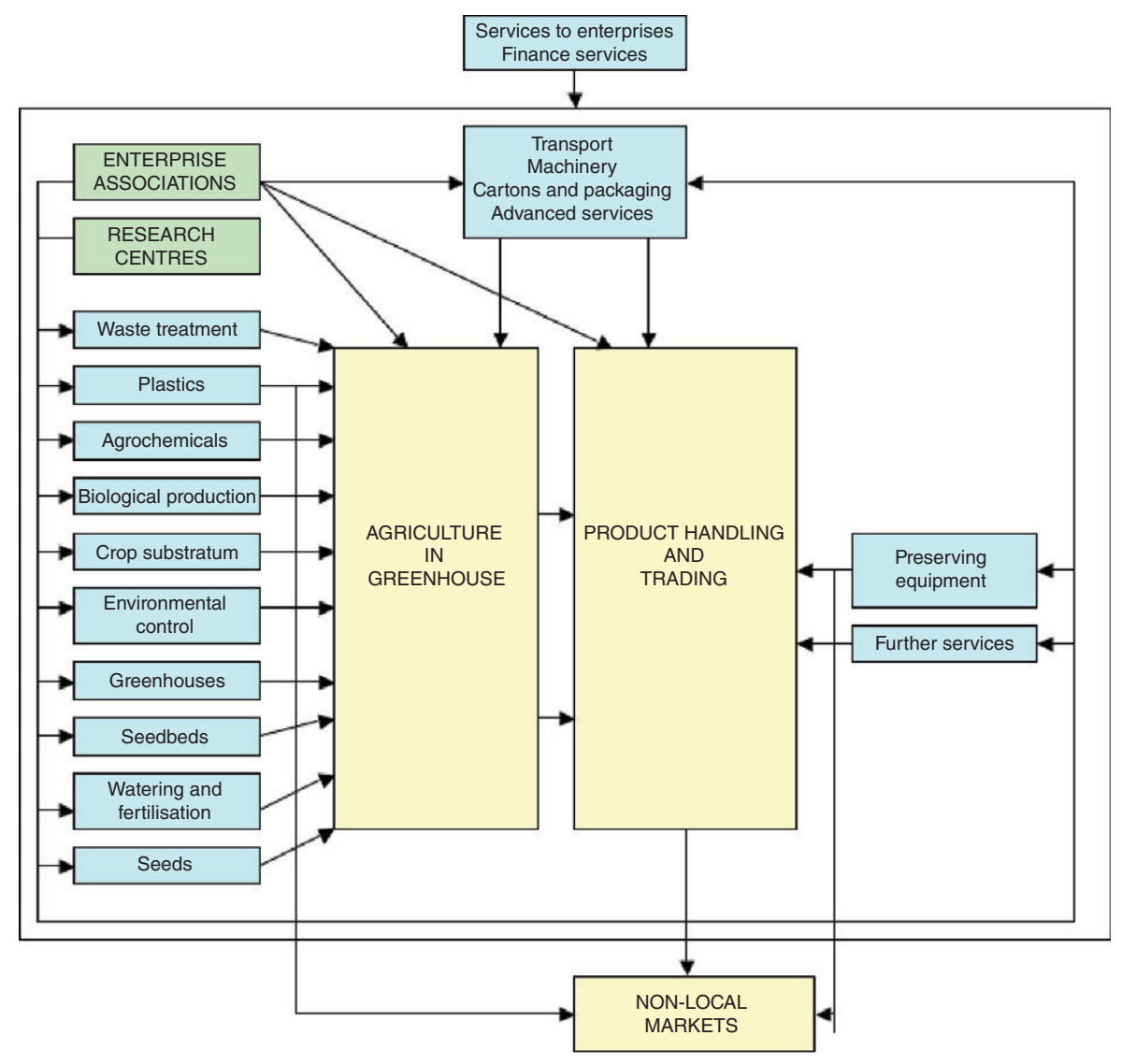

Figure 3: Production links of the agro-industrial system of Almeria Source: Ferraro and Aznar (2008).

the following significant figures: I4, ,oo enterprises, with an income of $€ 8,600 \mathrm{~m}$ per annum, with over 50,000 jobs created and with exports of $€_{I}, 700 \mathrm{~m}$ per annum (Ferraro and Aznar 2008). Further, the endogenous and local nature of this agroindustrial cluster is noteworthy. Local initiative has identified and set up most of the service activities (such as handling, marketing, transport, financial systems, information technology services and agronomic assessment). As regards industrial activities, in some sectors the firms are mainly local ones (plastics, irrigation and fertilisation, containers and greenhouses), and a growing number of local firms among them supply the technological inputs (seeds, biological production, machinery and agrochemical products) (Aznar-Sánchez and Sánchez-Picón 20Io).

Apart from the production links of secondary industries and services with primary activities which justify their creation, these industries and services have been creating a network of business and co-operative relationships which give the agro-industrial system strength and unification (Pérez-Mesa et al. 2009). ${ }^{4}$ 


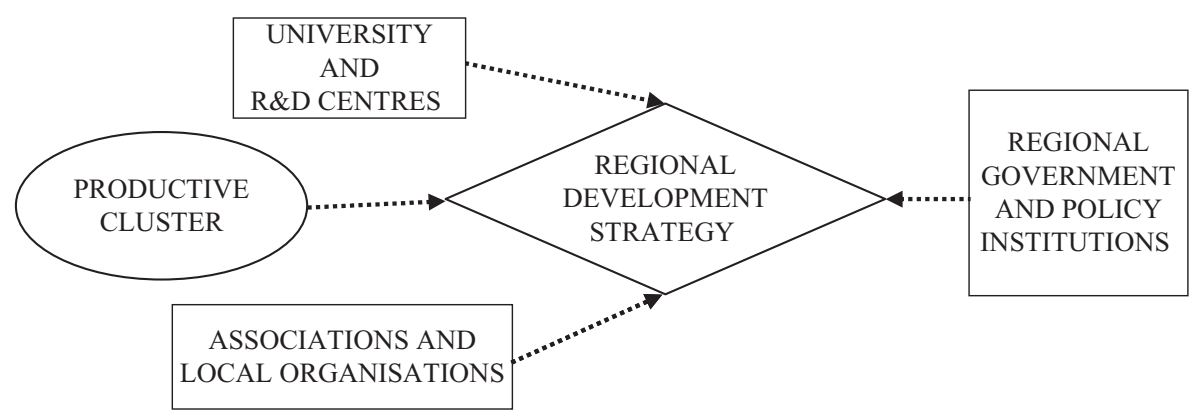

Figure 4: A neo-endogenous perspective of the current Almeria's development Source: Authors.

In recent years, the connection of this productive system with the different public institutions and research and development centres is also noteworthy. This leads us to consider a neo-endogenous tendency in the sector development, especially derived from the enormous qualitative leap in the sector based on widespread new knowledge. The province of Almería boasts research and development centres that focus their efforts on meeting the needs of this sector and favouring the development of innovations (Pallarés-Barberá 2002). ${ }^{5}$ The results are important in the development of technological processes that can be adapted to the special conditions of the sector in Almería. Thus, although many of the innovations are of an incremental nature and are not protected, the number of patents applied for by firms in the auxiliary industries of the productive system linked to intensive agriculture in Almería has increased considerably, accounting for 31\% of all Andalusian patents sought by the agrarian industry (Fundación Tecnova 2009).

Another component of development, from the neo-endogenous perspective, is the composition of an institutional framework that facilitates and stimulates relations between sector members and greatly contributes to its own growth. Consequently, companies in the sector are collaborating more and more closely with the university and provincial research centres. Local companies linked to the supply sector and other related sectors are also becoming actively involved in applied research works (Figure 4). In addition, research centres maintain important information exchanges with companies and also disseminate the results of their research (Galdeano-Gómez et al. 2008). One example that highlights this capacity to generate a combined response to changes in demand is the farmers' swift adoption of environmentally friendly production techniques with a view to meeting new market requirements and complying with the new EU Directive relating to the sustainable use of phytosanitary products. In only three years (2006-2009) integrated pest management has ceased to be the exception, replacing the hitherto usual chemical methods and becoming the norm. As a result, Almería has become the world's leading area using this system, ahead of countries such as Holland and Israel (Pérez-Mesa et al. 2009). The speed and magnitude of this change has been possible thanks to the availability of technical, human, corporate and institutional resources that are capable of carrying it out and 
also due to the perfect co-ordination between the private and public sectors. All the agents involved have made a great effort to achieve this. Producers and technicians have applied the new methods with great efficiency, supported by the ongoing training facilities that different institutions and organisms have made available. The auxiliary industry has researched and produced in Almería most of the natural predators necessary for plant treatment and pest control. The administration has fomented the implantation of these crop techniques by means of financial support to put them into practice and advertising campaigns (Aznar-Sánchez and SánchezPicón, 20I0).

Finally, a series of intangible assets have also grown up over the years (such as social capital, local know-how and relational capital) that provide the sector with great strength, competitive power and the flexibility with which to face new challenges, particularly in international markets (Pallarés-Barberá 2002). In the international context a series of modifications is taking place and creating an ever more global and competitive market. On the one hand, the European market is actively opening up, based on the multilateral commitments acquired (World Trade Organisation) and on the many bilateral and multilateral agreements and initiatives, particularly in the Mediterranean (García and Mastrostefano 2002). On the other hand, competitive conditions are likely to become considerably harder due to the emergence of vegetable-producing countries that have major advantages regarding costs which allow them to compete price-wise (such as Morocco, Turkey and Egypt) (Aznar 2006).

\section{Discussion and conclusions}

In the literature there is no a single exclusive model behind the driving forces of rural development. Instead there are multiple development trajectories resulting from various combinations of local, regional, national and global forces in specific circumstances.

Different research works have revealed the complexity of European rural regions, and indicated how the strategies and development policies have shown a mixture exogenous and endogenous development components (for example, Terluin 2003) as well as a combination of tangible and intangible assets (for example, Bryden and Hart 2004).

The successful economic growth of Almería province represents a clear example of this complexity. The process of changing comparative advantages into competitive advantages could not explained without the confluence of different components of development theories which have coincided in time, without specifying which element has been the most decisive in this development. In other words, the analysis has revealed that the development of each one of the periods described has been the result of the action of various endogenous and exogenous factors. Moreover, each one of the development theories analysed offers an explanation of the different contributions made by each one of the components. However, the progressive complexity of this phenomenon, in conjunction with the combined and complementary performance of each one of its components, makes it impossible to explain its development based merely on one theory; rather it is necessary to gather explanatory elements from all the components (High and Nemes 2007). 
Nevertheless, in this case study the complexity is greater. As previously shown, a common trajectory in European development strategies in recent decades is that they are based on rural multifunctionality and the consideration of agriculture as a misleading strategy (Ward et al. 2005). Although farming can be a competitive sector, this should be considered in most cases a complementary component of economic activity (Hassapoyannes et al. I998) due to its relative impact on rural development (Barkley and Wilson I992; Ward et al. 2005).

The singularity of this case is that intensive farming has allowed it to pass from a model based on absolute advantages during its beginnings to one characterised by its competitive advantages. At first, the sector was propelled by an initial advantage founded on the availability of a series of privileged natural resources that allowed production during times of the year when it was not possible in other European countries. However, over time a new series of dynamic advantages were generated as a result of the presence of certain advanced factors (including specialised personnel, local know-how, research and development centres and training centres), the accumulation of experience as well as technology and production innovations all functioning within a favourable institutional framework, accompanied by a flexible local production system. At present, Almería's horticultural sector constitutes a system with great capacity for innovation and improvement of its competitiveness. This is possible thanks to the generation from this sector of tangible and intangible assets, such as intense internal competition, competitive local suppliers, an appropriate environment for the investment and creation of new companies, extreme geographical concentration, highly motivated and dedicated members in the sector, the swift improvement of factors of production as well as efficient formal and informal methods of communication among members in the sector. As a whole it possesses favourable conditions for continued improvement and also a great versatility to adapt to market changes and other socio-economic issues. We should stress, however, the series of current problems that have to be dealt with: management of the immigrant workers, environmental impacts and the challenges from international markets. Although these problems have been dealt with suitably on the whole over recent years, this new context may require a process of re-adaptation. This change in direction is complex and may imply joint action by different agents related with this development, as has occurred in other cases in the European context (Shucksmith 2010).

Overall, this study provides some additional concerns about the paradigm of rural development. Therefore, the explanation of some specific agricultural and rural development still needs a mixture of development models (Terluin 2003). Moreover, if this re-mixture is possible, it is right to consider complementarity approaches as opposed to unidirectional ones.

\section{Notes}

* Corresponding author.

I These features are likely to be the reason behind the lack of regional case studies on this area, as most studies are concerned with the requirements and recommendations for European rural policy. 
2 Neo-endogenous thinking draws on institutionalist theories of development. Such theories maintain that the key to local development lies in building a local institutional capacity able both to mobilise internal resources and to cope with the external forces acting on a region. This perspective emphasises not only that economic or business development needs to be embedded in the region, but that the means of achieving this objective is through the participation of local actors in internal and external development processes.

3 As mentioned in the introduction, in the case of Almería, what stands out is the lack of relevance of the governmental system of support and of a policy of development planning in recent decades. Thus, after the colonisation policy in the I960s and I970s we have to wait until a few years after Spain's entrance into the EEC in I986 for the applications of structural funds to begin, from I989 onwards, and the first programmes of regional development. Later, especially in this sector, when the transition period was over in the midI990s, the effective application of the sectorial policies of the CAP (such as the European Commission Regulation 2200/96 of the Common Market Organization of Fruit and Vegetables). Nevertheless, for rural areas with competitive agriculture, whose CAP subsidies only account for I.6\% of agricultural income (García and Mastrostefano 2002), and with a relatively consolidated agro-industrial sector, rural development policies have been largely irrelevant and seldom applied. Indeed, except in certain specific rural areas of Almería, particularly mountainous ones that are less involved in greenhouse production, we find that certain LEADER I and LEADER II projects are put into practice, but their effect is barely relevant in the context of the province as a whole (Molina 2005) or in the development models described.

4 These authors admit that the presence in Almería's cluster of multinational firms in auxiliary industries (though only relevant in the seed sector), together with the pressure from major retailers, may tend to generate generic technology that is easily transferable to the competition, as has been observed in other sectors (see, for example, Almeida I996, for the semiconductors industry or Thompson 2002, for the textile industry). However, this scenario in Almería's agro-industry cluster, made up of small local firms, has allowed the generation of specific technology adapted to the needs of the local sector, which has also been the main testing area (Ferraro and Aznar 2008). On the other hand, Pérez-Mesa et al. (2009) consider that the other main function of the horticultural cluster is diffusion of technology, whether it be a newly implemented method or not, and primarily the speed with which the change takes place. The existence of a cluster oriented towards diffusion, which accelerates changes, entails positive complementary aspects as a result of being the first to adopt innovations (order effect). This effect is the result of the links between all the agents in the cluster, and is therefore in concordance with the existence of neoendogenous development.

5 Some centres are public institutions (such as the Andalusian Institute for Research and Training in Agriculture, Fisheries, Food and Ecological Production and the University of Almería), others private (such as Las Palmerillas Experimental Station founded by Cajamar and the Foundation for Auxiliary Technology in Agriculture) and some are mixed (such as the Innovation Centre of the Association of Horticultural Farmers and Exporters). Some have even become known worldwide, as is the case of both the Las Palmerillas Experimental Station and the University of Almería through the efforts of various research groups and its experimental farm (Ferraro and Aznar 2008).

\section{Acknowledgements}

This research was partially funded by the Spanish Ministerio de Ciencia e Innovación and Fondo Europeo de Desarrollo Regional aid ECO2008-02258. 


\section{References}

Almeida, P. (1996) Knowledge sourcing by foreign multinationals: patent citation analysis in the United States semiconductor industry. Strategic Management Journal I7 (Winter) pp. I55-I65

Aznar, J.A. (2006) La competencia entre la horticultura intensiva de Marruecos y España (Navarra: Thomson-Civitas)

Aznar, J.A. and A. Sánchez (2000) Inmigración en tierra de emigración: el caso de Almería. Economistas 86 pp. 97-II5

Aznar-Sánchez, J.A. and A. Sánchez-Picón (20I0) Innovación y distrito en torno a un 'milagro': la configuración del sistema productivo local de la agricultura intensiva de Almería. Revista de Historia Industrial 42 pp. I57-193

Baldock, D., J. Dwyer, P. Lowe, J.E. Petresen and N. Ward (200I) The nature of rural development: towards a sustainable integrated rural policy in Europe (London: Institute for European Environmental Policy)

Barkley, D.L. and P.N. Wilson (I992) Is alternative agriculture a viable rural development strategy? Growth and Change 23 (2) pp. 239-253

Bryden, J.M. (2003) Rural development situation and challenges in EU25 Keynote Speech, EU Rural Development Conference (Salzburg, November)

Bryden, J.M. and K. Hart eds (2004) A new approach to rural development in Europe: Germany, Greece, Scotland, and Sweden Mellen Studies in Geography (9)(Queenston, Lampeter and Lewiston: Edwin Mellen Press)

Buchenrieder, G., J. Möllers, K. Happe, S. Davidova, L. Fredrikson, A. Baley, M. Gorton, D.A. Kancs, J. Swinnen, L. Vranken, C. Hubbard, N. Ward, L. Juvancic, D. Milczarek and P. Mishev (2007) Conceptual framework for analysing structural change in agricultural and rural livelihoods. IAMO Discussion Paper No. II3 (Halle, Saale) Available online at http:|www.IAMO.de/dok/dpiı3.pdf Accessed 30 September 2010

Camagni, R. (I995) The concept of innovate milieu and its relevance for public policies in European lagging regions. Papers of the Regional Science Association 74 (4) pp. 3I7340

Cloke, P.J. (I997) Country backwater to virtual village? Rural studies and the cultural turn. Journal of Rural Studies I3 (4) pp. 367-375

Colino, J. and J.M. Martínez (2002) El agua en la agricultura del sureste español: productividad, precio y demanda. Mediterráneo Económico 2 pp. I99-22I

Consejería de Agricultura y Medio Ambiente (I99I) Recursos naturales y crecimiento económico en el 'Campo de Dalías' (Sevilla: Agencia de Medio Ambiente)

Cuddy, M.P. (2005) The rural economy: valued added creation, market sustainability, and the limits of policies measures. Pp. 205-22I in M. McEldowney, M. Murray, B. Murtagh and K. Serrett eds, Planning in Ireland and beyond: multidisplinary essays in honour of John V. Greer (Belfast: School of Environmental Planning Queen's University)

Downward, S.R. and R. Taylor (2007) An assessment of Spain's Programa AGUA and its implications for sustainable water management in the province of Almería, southeast Spain. Journal Environmental Management 82 (2) pp. 277-289

Dwyer, J., N. Ward, P. Lowe and D. Baldock (2007) European rural development under the Common Agricultural Policy's 'second pillar': institutional conservatism and innovation. Regional Studies 4I (7) pp. 873-888

Esposti, R. and F. Sotte (2002) Institutional structure, industrialization and rural development: an evolutionary interpretation of the Italian experience. Growth and Change 33 (I) pp. 3-4I

European Commission (2007) Agriculture in the European Union - statistical and economic information 2006 (Brussels: Directorate-General for Agriculture and Rural Development)

Ferraro, F.J. ed. (2000) El sistema productivo almeriense y los condicionamientos hidrológicos (Madrid: Civitas) 
Ferraro, F.J. and J.A. Aznar (2008) El distrito agroindustrial de Almería: un caso atípico. Mediterráneo Económico I3 pp. 353-382

Flynn, A. and P. Lowe (I994) Local politics and rural restructuring: the case of the contested countryside. Pp. 247-259 in D. Symes and A.J. Jansen eds, Agricultural restructuring and rural change in Europe (Wageningen: Agricultural University)

Fundación Tecnova (2009) Tecnómetro. Observatorio económico y de innovación de la industria auxiliar de la agricultura (Almería: Fundación Tecnova)

Galdeano, E. and J. De Pablo (I999) La agricultura intensiva en el sureste español: análisis de los determinantes de su desarrollo. Economistas 8I pp. 9I-IO3

Galdeano-Gómez, E., J. Céspedes-Lorente and J. Martínez-del-Río (2008) Environmental performance and spillover effects on productivity: evidence from horticultural firms. Journal of Environmental Management 88 (4) pp. I552-I56I

García, T. and M. Mastrostefano (2002) Algunas reflexiones sobre los retos del sector europeo de las frutas y hortalizas. Mediterráneo Económico 2 pp. 83-99

García-Latorre, J., J. García-Latorre and A. Sánchez-Picón (200I) Dealing with aridity: socioeconomic structures and environmental changes in an arid Mediterranean region. Land Use Policy I8 (I) pp. 53-64

Gómez, D. (2003) La horticultura en Almería. Bases para un Plan de Ordenación Territorial y Gestión Medioambiental (Almería: Cajamar)

Hassapoyannes, K., I. Daskalopoulou and N. Petrou (I998) An introduction to different conceptualisations of endogenous rural development. Cahiers Options Mediterraneennes $30 \mathrm{pp}$. I-9 (Workshop on Research Network on Endogenous Rural Development in the Mediterranean Region, NEDMED, I997/03, Cypurs)

High, D. and G. Nemes (2007) Social learning in LEADER: exogenous, endogenous and hybrid evaluation in development. Sociologia Ruralis 47 (2) pp. IO3-II9

Instituto Nacional de Estadística (2008) Estadísticas (Madrid: INE) Available online at http:// www.ine.es Accessed 30 September 2010

Lowe, P., J. Murdoch, T. Marsden, R. Munton and A. Flynn (1993) Regulating the new rural spaces: the uneven development of land. Journal of Rural Studies 9 (3) pp. 205223

Martínez-Paz, J., F. Martínez-Carrasco and R. Dios-Palomares (200I) Analysis of the evolution of protected horticulture in Almeria area: cycles, structure and growth. Acta Horticulture 559 pp. 7I3-7I 8

Molina, J. ed. (2005) La economía de la provincia de Almería (Almería: Caja Rural Intermediterránea, Cajamar)

Mota, J.F., J. Peñas, H. Castro and J. Cabello (I996) Agricultural development vs. biodiversity conservation: the Mediterranean semiarid vegetation in El Ejido (Almería, southeastern Spain). Biodiversity and Conservation 5 (12) pp. I597-I6I7

Pallarés-Barberá, M. (2002) Enterprise embeddedness and industrial innovation in Spain: and overview. Pp. II3-I25 in M. Taylor and S. Leonard eds, Embeddedness enterprise and social capital (Aldershot: Ashgate)

Pausewang, S. (I995) 'Productionism' or 'sustainability', 'subsistence' or 'market adapation'. Social consequences of different concepts for agricultural life on family farms in remote areas in poor and rich societies. Paper presented at the XVI congress of the European society for rural sociology (Prague, Czech Republic, 3 July-4 August)

Pérez-Mesa, J.C. (2007) Should Almería (Spain) have to worried, thinking that their tomato export is currently affected by international competition? Agricultural Economics Review 8 (2) pp. $42-54$

Pérez-Mesa, J.C., E. Galdeano-Gómez and M. Galera (2009) Technology diffusion in agrocluster: the role of multinational companies in southeastern Spain (Budapest: IAMA I9 Annual Food and Agribusiness World Forum and Symposium, 20-2I June)

Ray, C. (200I) Culture economies (Newcastle: CRE Press) 
Ray, C. (2003) Governance and neo-endogenous development. Review paper for Defra, the Countryside Agency and the Economic \& Social Research Council (London: Defra) Available online at http://www.defra.gov.uk/rural/research/default.htm No longer available online

Shucksmith, M. (2000) Endogenous development, social capital and social inclusion: perspectives from LEADER in the UK. Sociologia Ruralis 40 (2) pp. 208-2I8

Suchacek, J. and J. Malinovsky (2007) Regional development in transitional economies after 1989: reformation or deformation? Paper presented at the $47^{\text {th }}$ congress of the European regional science association (Paris, 2007)

Shucksmith, M. (2010) Disintegrated rural development? Neo-endogenous rural development, planning and place-shaping in diffused power contexts. Sociologia Ruralis 50 (I) pp. I-I3

Tarditi, S. (2000) Structural funds and rural development: suggestions from the Italian experience. Pp. $73-83$ in C. Csaki and Z. Lerman eds, The challenge of rural development in the EU accession countries (Sofia, Bulgaria: Third World Bank/FAO EU Accession Workshop, I7-20 June)

Terluin, I.J. (2003) Differences in economic development in rural regions of advanced countries: an overview and critical analysis of theories. Journal of Rural Studies I9 (3) pp. 327-344

Terluin, I.J. and J.H. Post (I999) Employment in leading and lagging rural regions of the EU. Summary report of the RUREMPLO Project, February, Rapport 4.99.IO, Agricultural Research Institute (LEI) (The Hague)

Terluin, I.J. and J.H. Post eds (2000) Employment dynamics in rural Europe (Wallingford: CABI Publishing)

Thompson, R.E. (2002) Clustering of foreign direct investment and enhanced technology transfer: evidence from Hong Kong garment firms in China. World Development 30 (5) pp. $873-889$

Tout, D. (I990) The horticulture industry of Almería province, Spain. The Geographical Journal I56 (3) pp. 304-3I2

United Nations Environment Programme (UNEP) (2005) One planet, many people: atlas of our changing environment (New York: UNEP)

Van der Ploeg, J.D. and G. van Dijk eds (I995) Beyond modernization: the impact of endogenous rural development (Assen: Van Gorcum)

Van der Ploeg, J.D. and A. Long eds (I994) Born from within: practice and perspectives of endogenous rural development (Assen, Netherlands: Van Gorcum)

Vázquez-Barquero, A. (2002) Endogenous development networking, innovation, institutions and cities (London and New York: Routledge)

Ward, N. (2002) Integrated rural development - a review of the literature (Trondheim: Centre for Rural Research, University of Trondheim)

Ward, N., J. Atterton, K. Tae-Yeon, P. Lowe, J. Phillipson and N. Thompson (2005) Universities, the knowledge economy and the 'neo-endogenous rural development'. Discussion Paper, No. I, Centre of Rural Economy (Newcastle University)

Ward, W.A. and J.C. Hite (I998) Theory in rural development: an introduction and overview. Growth and Change 29 (3) pp. 245-258

Yamamoto, T. (2007) East meets west in an entrepreneurial farming village in Japan: endogenous development theories and economic gardening practices. Business and Economic History Online 5 pp. I-I4

Yin, R. (I989) Case study research: design and methods (London: Stage)

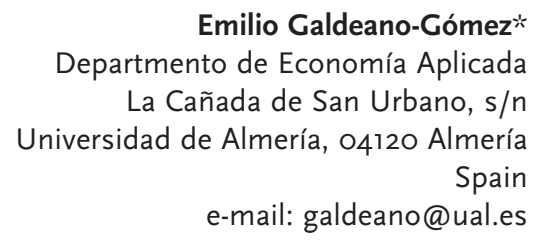

(C) 2010 The Authors. Sociologia Ruralis (c) 2010 European Society for Rural Sociology.

Sociologia Ruralis, Vol 51, Number 1, January 2011 
José A. Aznar-Sánchez Departmento de Economía Aplicada La Cañada de San Urbano, s/n Universidad de Almería, 04120 Almería Spain e-mail: jaznar@ual.es

Juan C. Pérez-Mesa Departamento de Gestión y Dirección de Empresas La Cañada de San Urbano, s/n Universidad de Almería 04120 Almería Spain e-mail: juancarl@ual.es 